\title{
Physicochemical and functional properties of spineless, short-spines, and long-spines sago starch
}

\author{
BUDI SANTOSO, ZITA LETVIANY SARUNGALLO", ANGELA MYRRA PUSPITA \\ Department of Agricultural Product Technology, Faculty of Agricultural Technology, Universitas Papua. Jl. Gunung Salju, Amban, Manokwari-98314, \\ West Papua, Indonesia. `email: zlsarungallo@yahoo.com.
}

Manuscript received: 20 August 2020. Revision accepted: 15 December 2020.

\begin{abstract}
Santoso B, Sarungallo ZL, Puspita AM. 2021. Physicochemical and functional properties of spineless, short-spines, and longspines sago starch. Biodiversitas 22: 137-143. Starch application in the food and non-food industries is influenced by their properties. The aim of this research was to characterize the physicochemical and functional of spineless, short-spines, and long-spine sago starch. Starch morphology for all types had an oval shape with a smooth surface, which was proved by the X-ray diffraction analysis. The proximate composition did not differ for all types of sago, except the protein of spineless sago type was slightly higher but it did not affect the profile and gelatinization process. The amylose content of spineless, short spines and long spine of sago starch was 33.61 $\% \mathrm{db}, 38.47 \% \mathrm{db}$, and $37.59 \% \mathrm{db}$, respectively; categorized as a high in amylose then tends to be stickyless. The value of peak viscosity and setback of spineless sago $(7571.0 \mathrm{cP}$ and $1495.0 \mathrm{cP})$ and long spines sago $(7608.0 \mathrm{cP}$ and $923.0 \mathrm{cP})$ were higher than the short spines sago starch $(1271.0 \mathrm{cP}$ and $538.0 \mathrm{cP})$. Therefore, the spineless and the long spines sago starch are suitable as thickener and fillers, while the short spines sago starch is suggested for cakes and bakery products because it will not harden when the product is cold.
\end{abstract}

Keywords: Functional, native starch, physicochemical, sago type

\section{INTRODUCTION}

Starch is the main storage carbohydrate and abundant storage of plants that is used for food. It is found in many different plant organs, including seeds, fruits, tubers, and roots, where it is used as a source of energy. Some of them are sweet potato, potato, wheat, rice, corn, and cassava. However, most of food production in the world uses nonwaxy maize (generally, it has an amylopectin content of approximately $72 \%$ ) because it has low amylopectin content and higher relative crystallinity (Liu et al. 2011). Sago is a potential source of starch. Sago starch can be obtained by extracting sago tree trunks, whether traditional, semi-modern, or modern. Application of sago starch for food and non-food industries is undeniable. In food products, sago starch can be made for noodles, bread, biscuit, vermicelli, and thickener in the production of soup and baby food and food packaging films (Bhat et al. 2013). Sago starch is also widely used together with rice, corn, and potatoes to manufacture various food products. Cookies are still well accepted by consumers through substitution of wheat flour with sago starch up to 40 percent (Konuma 2018).

In Papua, there are many sago accessions. Characteristics of sago accessions are distinguished by their qualitative characteristics, such as shoot color, shape and length of spine, leaf midribs, stem diameter, color of starch, canopy shape, nutrient and mineral content, and starch productivity (Limbongan 2007). Furthermore, based on the presence of spine, there are two types of sago, namely spineless sago and spines sago (Dewi et al. 2016). While, spiny sago can be classified into two groups, namely short spines, and long spines sago types. Therefore, in general, there are three types of sago based on the morphology of their spines, namely spineless sago, short spines sago (spines length ranges from $1-5 \mathrm{~cm}$ ), and long spines sago (spines length ranges from $6-20 \mathrm{~cm}$ ).

Studies about the influence of environmental conditions on sago growth and sago productivity have been conducted by Dewi et al., (2016), Muhidin et al., (2016), and Yater et al., (2019). Unfortunately, study about the characteristics of physicochemical and functional of sago starch from three types of sago (spineless, short spines, and long spines) from Papua have never been reported, while it is assumed that each type of sago has different physicochemical characteristics. The information about the structure of surface morphology of starch granule, particle diameters of granules, relative crystallinity, the amylose to amylopectin ratio, and chemical composition will affect the application of starch in both the food industry and non-food industries. Accordingly, the purpose of this study was to determine the physicochemical and functional characteristics of spineless sago, short spines sago, and long spines sago, with the result that its application can be precisely in accordance with its characteristics.

\section{MATERIALS AND METHODS}

\section{Materials}

Starches were isolated from spineless sago palm, short spines sago palm, and long spines sago from West Papua Province. Description of the type of short spines sago is having long spines ranging from $1-5 \mathrm{~cm}$ and spines 
distribution rarely on the petiole. While, the type of long spines sago is having long spines ranging from $6-20 \mathrm{~cm}$ and the spines distribution plenty on the petiole. Performance of the sample sago types is shown in Figure 1.

\section{Sago starch extraction}

Extraction process of sago starch using the small-scale method (Darma and Istalaksana 2011). Sago starch preparation was done through steps: cutting trunk into log, debarking, rasping, extracting, sieving, and settling. The homogenate was sieved through a 100 mesh filter and allowed to settle. The precipitate was carefully washed three times using clean water to remove impurities compounds and improve sago starch color. Finally, the starch was dried in a combination of air drier and dryer oven until the water content was around $12 \%$, and was packed in plastic container for analysis. The chemicals used were various analytical grades for analysis of proximate, starch content, amylose, and amylopectin contents.

\section{Scanning electron microscope (SEM) observation}

The morphology of sago starch samples was examined using SEM S-5400N Scanning Electron Microscope (Hitachi Ltd., Tokyo, Japan), at an accelerating voltage of $15 \mathrm{kV}$ following the method of Santoso et al. (2015). The samples were spread thinly and evenly on circular metal stubs using double-sided adhesive tape.

\section{Proximate analysis}

\section{Water content}

Moisture content was measured using air-oven following the official methods of AOAC (2005). Approximately $1 \mathrm{~g}$ of the sample was put in a constant weight material test chamber. Set the oven to $105^{\circ} \mathrm{C}$. Place the sample in the oven and allow it to weigh constant. The percentage of moisture content was calculated as:
$\% \mathrm{MC}=\frac{\text { Wet weight }- \text { weight after drying }}{\text { Wet weight }} \times 100$

\section{Protein content}

The total nitrogen amount in the sample was determined according to method described by AOAC (2005), using Auto Distillation Unit. A nitrogen-to-protein conversion factor of 6.25 was used for the determination of protein present in the samples.

\section{Fat content}

Determination of fat/lipid content was performed following Soxtec method (AOAC 2005). Petroleum ether was used for the extraction, whereas percentage of lipid was obtained following equation below:

$\%$ Fat $=\frac{\text { Weight }(\text { extraction }+ \text { residue })-\text { Weight }(\text { extraction cup })}{\text { Weight sample }} \times 100$

\section{Ash content}

A dry ashing method was used to determine the ash content (AOAC 2005). The sample is commonly ignited at $550-600^{\circ} \mathrm{C}$ to oxidize all organic materials without flaming. The inorganic residue that does not volatilize at that temperature is called ash. The ash content is determined from the loss of weight, which occurs from complete oxidation of sample.

\section{Carbohydrates}

Carbohydrates content was determined by difference as follows (AOAC 2005):

Carbohydrate $(\%)=100-($ moisture $\%+$ protein $\%+$ ash $\%+$ fat $\%)$

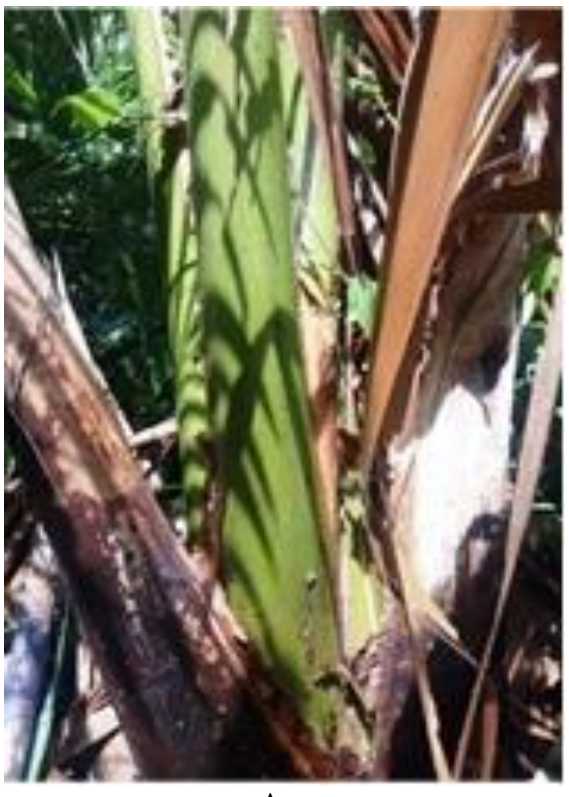

$\mathbf{A}$

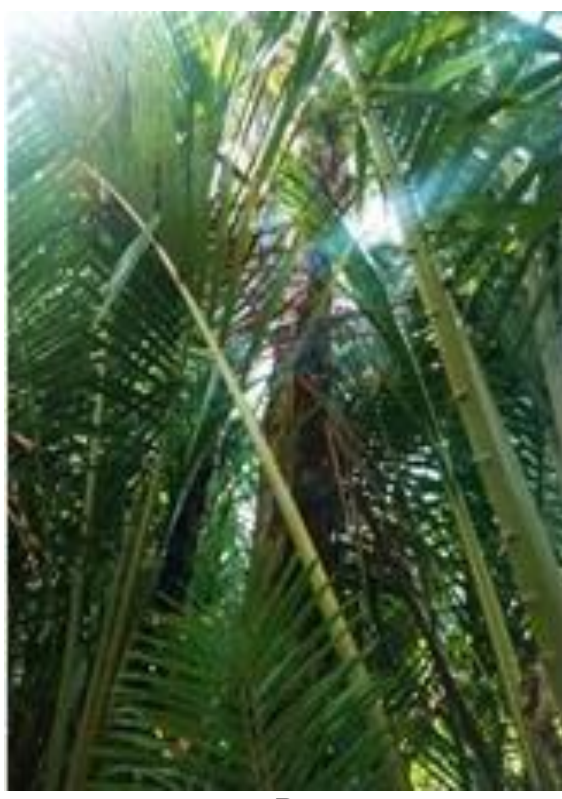

B

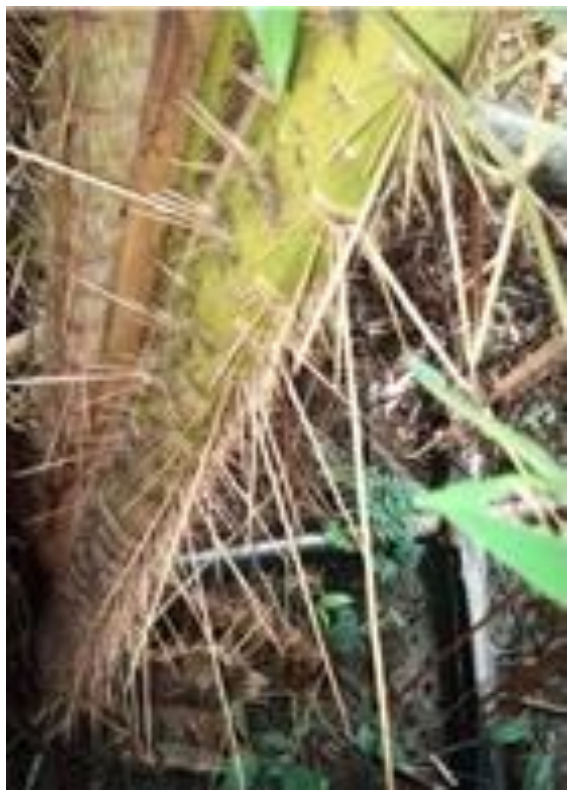

C

Figure 1. The three sago types: A. Spineless sago, B. Short spines sago, C. Long spines sago 


\section{Starch content analysis}

Starch content was determination by Luff Schroll method (SNI 2011). Approximately $25 \mathrm{ml}$ filtrate added by $25 \mathrm{ml}$ Luff Schroll solution in Erlenmeyer glass. This glass was connected by reverse cooler and boiled for $10 \mathrm{~min}$. After boiling, the solution was cooled and added $15 \mathrm{ml}$ of $\mathrm{KI} 20 \%$ and $25 \mathrm{ml}$ of $\mathrm{H}_{2} \mathrm{SO}_{4} 25 \%$ and store in dark place for $30 \mathrm{~min}$. Then titrate the solution with $0.1 \mathrm{~N}$ of $\mathrm{Na}_{2} \mathrm{~S}_{2} \mathrm{O}_{3}$ using 2-3 $\mathrm{ml}$ starch as indicator. The blank treatment was made by the same procedure using distilled water to substitute the sample solution.

\section{Amylose and amylopectin determination}

The method by Gujral and Rosell (2004) was used for determination of amylose and amylopectin. Approximately $50 \mathrm{mg}$ of starch was dispersed in $1.0 \mathrm{ml}$ of distilled water in an Eppendorf tube using a wire rod. Heating at $90^{\circ} \mathrm{C}$ for $15 \mathrm{~min}$ in a water bath. The paste was cooled in ice water bath to room temperature, and then centrifuged at $3000 \times \mathrm{g}$ at $4{ }^{\circ} \mathrm{C}$ for $10 \mathrm{~min}$. After removing the supernatant, the pasted samples were defatted with methanol and $20 \mathrm{mg}$ of defatted sample were extracted with $1 \mathrm{M} \mathrm{KOH}$ for $2 \mathrm{~min}$ and centrifuged for $5 \mathrm{~min}$ at $16000 \times \mathrm{g}$. To $250 \mu \mathrm{l}$ of the supernatant, $1.0 \mathrm{ml}$ of Lugol's iodine solution $(2 \mathrm{~g}$ potassium iodide and $1.3 \mathrm{~g}$ of iodine in $100 \mathrm{ml}$ distilled water), and water $(7.5 \mathrm{ml})$ were added and then neutralized with $1 \mathrm{M} \mathrm{HCl}$. The solution was diluted 10 times and absorbance measured at 630 and $520 \mathrm{~nm}$ for amylose and amylopectin determination, respectively.

\section{X-ray diffraction (XRD) analysis}

The determination of the XRD pattern and the relative crystallinity was performed using a Rigaku D/MAX 2500 $\mathrm{V}$ diffractometer (Rigaku, Japan) following the method of Liu et al. (2011). The starch about $50 \mathrm{mg}$ was placed in a square glass cell $(2 \mathrm{~cm} \times 2 \mathrm{~cm})$ and exposed to an $\mathrm{X}$-ray beam, operated at $40 \mathrm{kV}$ and $30 \mathrm{~mA}$, with $\mathrm{Cu} \mathrm{K} \alpha$ radiation (Ni filter disc). The $2 \theta$ scanning range was $3-60^{\circ}$, which covers all the significant diffraction peaks of starch crystallites. The diffraction slit was operated at $0.5-10 \mathrm{~mm}$ and the scan rate was $3 \% \mathrm{~min}$. The crystallinity portion was the area above the smooth curve and the amorphous portion was the area between crystallinity area and a linear baseline.

\section{Rapid Visco analysis (RVA)}

Gelatinization profile of sago starch was analyzed by Rapid Visco Analyser (PERTEN Rapid Visco Analyzer 4500, Canada) according to Steffe (1996) method. Approximately $3.0 \mathrm{~g}$ of starch (db) was added $25 \mathrm{~mL}$ of distilled water. The suspension was heated from $50^{\circ} \mathrm{C}$ to $95^{\circ} \mathrm{C}$ at a rate $6^{\circ} \mathrm{C} / \mathrm{min}$, then it holding for $5 \mathrm{~min}$. The solution was then cooled from $95^{\circ} \mathrm{C}$ to $50^{\circ} \mathrm{C}$ at the rate $6^{\circ} \mathrm{C} / \mathrm{min}$ and it holding for $2 \mathrm{~min}$. The amylograph profile of starch will be detected.

\section{Data analysis}

Chemical properties data were subjected to an analysis of variance (ANOVA) using Statistical Analysis System (SAS) program version 9.1.3, followed by Duncan Multiple Region Test (DMRT) was to describe means with 95\% confidence for every treatment. All the experiments were conducted in duplicate $(n=2)$.

\section{RESULTS AND DISCUSSION}

\section{Morphology and size of sago starch}

Scanning electron microscope (SEM) has been the main tool used to study morphology and the structural characteristics of starch granules. The shape of the starch granules is various depend on the botanical source, including spherical, oval, polygonal, disk (lenticular), elongated, and kidney shapes. Normally, the shape of the potato starch granules is oval and spherical shape, wheat starch is triticale, normal and waxy maize starches are spherical and polygonal. Based on the SEM (Figure 2), the shape of the native starch granules of three types of sago was mainly oval (whole and truncated), but some were spherical and with pores as smoothness in their surface. The shape of the starch did not change and their granule surface was smooth indicated that the starch did not undergo physical changes during the starch extraction process. This result agreed with Santoso et al. (2015), the native sago starch has smooth surface and exhibited few holes. While, Barrera et al.-(2013) stated that the granule surface was smooth and flat in the native starch of wheat, although some appear to mark sites, where granules were in close contact with each other. On the other hand, the starch that has changed shape with a rough starch surface shows that it has been damaged to the starch granule. The damage of the starch granule surface will facilitate the hydrolysis process compared to the surface of the intact granule. Therefore, the information on external surface of starch granules is very important in modifying process.

The starch size is varies depending on their botanical origins, such as rice $(3-10 \mu \mathrm{m})$, corn $(5-20 \mu \mathrm{m})$, wheat (22$36 \mu \mathrm{m})$, or cassava $(5-25 \mu \mathrm{m})$, and potato $(15-85 \mu \mathrm{m})$ (Nadiha et al. 2010; Zeng et al. 2011). The starch size (Figure 2) shows the diameter of starch granules for three types of sago was same with dominated by size of around $40 \mu \mathrm{m}$, and this result agreed with Santoso et al. (2015). Zhu (2019) also reported the sago starch granules size distribution is broad, ranging from 10 to $50 \mu \mathrm{m}$. Previous studied was reported that crop development and part of the trunk also influence sago granule size. Starch granule size was increased during crop development which at Angau Tua stage (mature fruiting), most granule sizes have larger size (Uthumporn et al. 2014). Achudan et al. (2020) also reported sago starch from bottom part of palm has bigger particle than starch from top part of palm. This result shows that sago starch size was bigger, and needs a longer hydrolysis time than starch of rice, corn, wheat, and cassava. Generally, small starch granules are first hydrolyzed rather than are large one for all starches. 

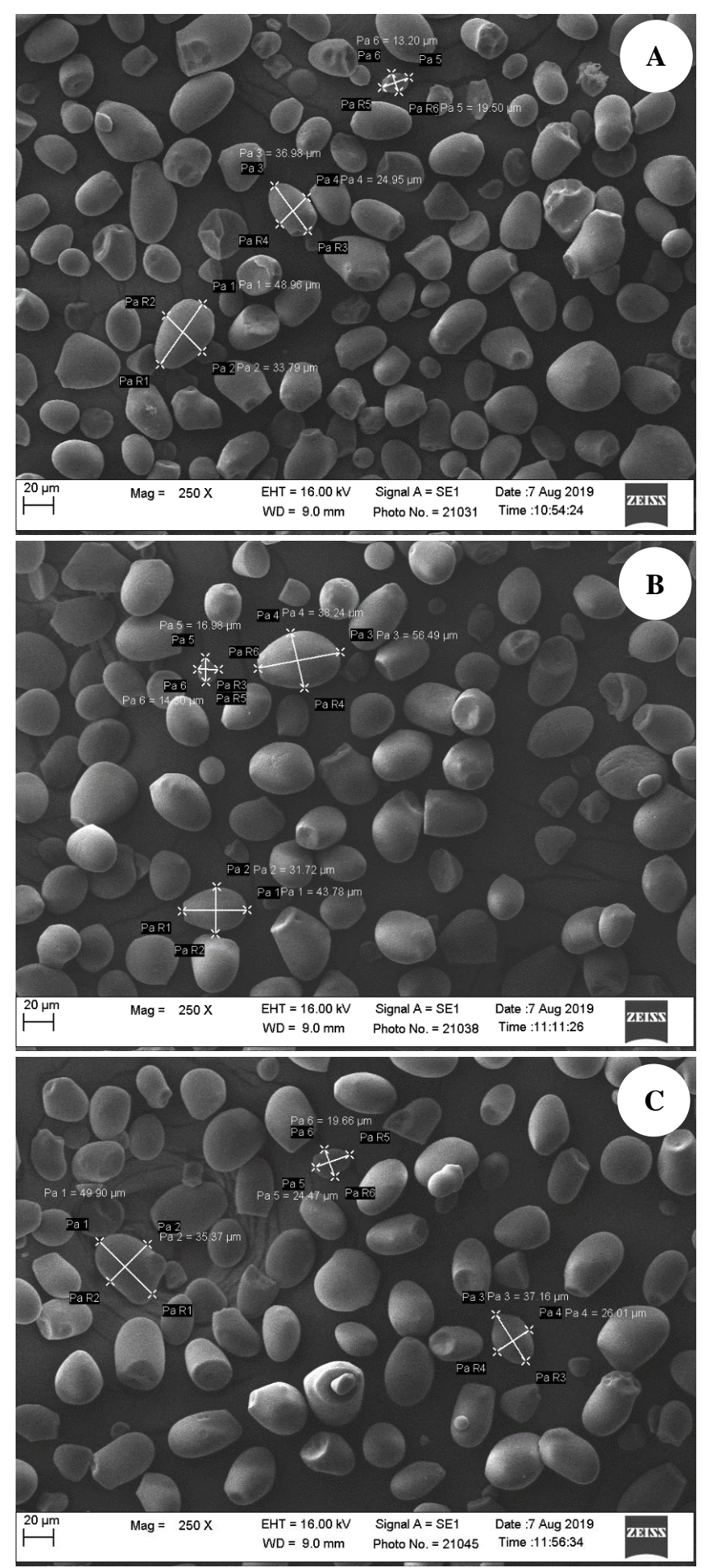

Figure 2. SEM images of shape and size starch granules from three types of sago (250x magnification). A. Spineless sago, B. Short spines sago, C. Long spines sago

\section{Proximate composition}

The moisture content normally equilibrates to approximately $12 \%$ or less in starches. While, based on the Indonesian National Standard for sago starch (SNI, 1995), the required water content of sago starch is a maximum of $13 \%$, because the water content is safe for various reactions or damage caused by fungi or bacteria. Data in Table 1, show that the water content of spineless sago, short spines sago, and long spines sago types range 12 to $13 \%$ (wb), which means that the water content of sago starch in this study was in the range of required water content. The moisture content of short spines sago was higher than the others probably caused it had stronger water bonds in the starch matrix. According to Labuza (1984), water that is strongly bonded in the matrix of food will form hydrates and the bonds are ionic, then it relatively difficult to remove or evaporate.

Sago starch (Metroxylon sago sp.) consists of very low levels of minor components such as protein $(\sim 0.3 \%)$, lipids $(\sim 0.1 \%)$, fiber $(\sim 0.3 \%)$, and ash $(\sim 0.4 \%)$ (Zhu 2019). Fat content of starch of three types of sago (Table 1) was ranged from $0.13 \%(\mathrm{db})$ to $0.35 \%(\mathrm{db})$, and the types of sago was not given a significant difference $(\mathrm{P}<0.05)$. Protein content of sago starch was ranged from $1.11 \%(\mathrm{db})$ to $1.35 \%(\mathrm{db})$ and it's was significantly different $(\mathrm{P}<0.05)$, in which protein content of spineless sago was different higher than the other two types. The protein content of sago starch was lower than 11 cultivars of potato starches (Alvani et al. 2011), and indicates that potato starch is purer than sago starch. Sago is a plant as a source of carbohydrates and data in Table 1 shows that carbohydrate content in the three types of sago varied from $96.95 \%$ (db) to $97.72 \%(\mathrm{db})$, and it was not significantly different $(\mathrm{P}<0.05)$ among of the three types of sago. While ash content of three types of sago was not significantly different among the sago types and the ash content obtained in this study was lower than the Indonesian National Standard for sago starch (SNI, 1995) is a maximum of $0.5 \%$.

\section{Starch content}

Starch content (Table 2) was not significantly different ( $\mathrm{P}<0.05)$ for the three types of sago, with starch ranges between $95.05 \%(\mathrm{db})-96.26 \%(\mathrm{db})$. This indicates that sago starch used in this study has high purity and does not contain many non-starchy compounds. The starch content in this study was slightly higher than those obtained by Uthumporn et al., (2014) ranged from $91.69 \%-94.24 \%$ for sago starch. This difference is might be influenced by folk variety, environmental condition, harvesting time, and processing (Yamamoto 2011).

\section{Amylose and amylopectin content}

Several researchers found that the amylose content in different types of sago ranged from 21-30\% (Zhu 2019). This variation can be affected by quantification method used, soil condition, and starch from Sago palm grown in mineral soil with higher amylose content than that of grown in peat soil (Uthumporn et al. 2014).

Data in Table 2 showed that amylose content of sago starch of spineless sago was significantly lower $(\mathrm{P}<0.05)$ compared to the two types of short and long sago. Amylose and amylopectin are two fractions of starch that influence the adhesiveness and hardness of food products. According to Meullnett et al. (2000) amylose content of starches classified into three groups; low amylose content $(<20 \%)$, medium amylose content (20-25\%), and high amylose content $(>25 \%)$. 
Table 1. Proximate composition of three types of sago

\begin{tabular}{lccc}
\hline \multicolumn{1}{c}{ Parameters } & \multicolumn{3}{c}{ Types of sago } \\
\cline { 2 - 4 } & Spineless sago & Short spines sago & Long spines sago \\
\hline Moisture $(\% \mathrm{wb})$ & $12.00 \pm 0.14 \mathrm{a}$ & $13.00 \pm 0.43 \mathrm{~b}$ & $11.58 \pm 0.26 \mathrm{a}$ \\
Fat $(\% \mathrm{db})$ & $0.35 \pm 0.04 \mathrm{a}$ & $0.21 \pm 0.09 \mathrm{a}$ & $0.13 \pm 0.01 \mathrm{a}$ \\
Protein $(\% \mathrm{db})$ & $1.35 \pm 0.07 \mathrm{~b}$ & $1.13 \pm 0.09 \mathrm{a}$ & $1.11 \pm 0.00 \mathrm{a}$ \\
Carbohydrate $(\% \mathrm{db})$ & $96.95 \pm 0.16 \mathrm{a}$ & $97.62 \pm 0.60 \mathrm{a}$ & $97.72 \pm 0.34 \mathrm{a}$ \\
Ash $(\% \mathrm{db})$ & $0.07 \pm 0.00 \mathrm{a}$ & $0.09 \pm 0.01 \mathrm{a}$ & $0.09 \pm 0.01 \mathrm{a}$ \\
\hline
\end{tabular}

Note: *Value followed by different letter within a row of each treatment indicate significant differences $(\mathrm{P}<0.05)$

Table 2. Starch, amylose, amylopectin, and relative crystallinity of three types of sago

\begin{tabular}{lccc}
\multicolumn{1}{c}{ Parameters } & Spineless sago & Short pines sago & Long spines sago \\
\hline Starch $(\% \mathrm{db})$ & $95.05 \pm 0.24 \mathrm{a}$ & $96.26 \pm 0.26 \mathrm{~b}$ & $95.61 \pm 0.24 \mathrm{ab}$ \\
Amylose $(\% \mathrm{db})$ & $33.61 \pm 0.11 \mathrm{a}$ & $38.47 \pm 0.13 \mathrm{~b}$ & $37.59 \pm 0.10 \mathrm{~b}$ \\
Amylopectin $(\% \mathrm{db})$ & $66.40 \pm 0.11 \mathrm{~b}$ & $61.54 \pm 0.13 \mathrm{a}$ & $62.41 \pm 0.10 \mathrm{a}$ \\
Relative cristallinity $(\%)$ & $34.40 \pm 1.06 \mathrm{a}$ & $35.30 \pm 1.13 \mathrm{a}$ & $36.20 \pm 1.20 \mathrm{a}$ \\
\hline
\end{tabular}

Note: *Value followed by different letter within a row of each treatment indicate a significantly different $(\mathrm{P}<0.05)$

The starch with high amylose content is not suitable for the adhesive industry because it is stickyless, but more suitable for the paper and textile industries. Amylose is primarily linear with $\alpha-1-4$ linked glucosyl units. Amylose generally consists of semi-crystalline parts and insoluble in water. While amylopectin is dominant consisting of amorphous parts and dissolves in water, then the texture will be fluffier and softer.

\section{X-ray diffraction (XRD) of sago starch}

XRD has been used to study of the crystal structure and crystallinity of starch. A typical diffraction pattern of starch can be classified into three patterns, namely A, B, and C types. According to Cai et al. (2014), A-type starch of XRD pattern has diffraction peaks at around $2 \theta=15^{\circ}, 23^{\circ}$, $17^{\circ}$, and $18^{\circ}$. B-type starch of XRD pattern has diffraction pattern at around $2 \theta=5^{\circ}, 15^{\circ}, 17^{\circ}, 20^{\circ}, 22^{\circ}$, and $24^{\circ}$. While C-type starch is a mixture of both A-type and B-type crystallinities. Zhang et al., (2012) stated that the A-type polymorphs of starch are mainly presented in cereal or rhizome, such as corn, wheat, and rice. While B-type starch is usually obtained from tubers, such as potatoes ( $\mathrm{Li}$ et al. 2012).

Based on the X-ray photograph (Figure 3), the X-ray diffractograms of the starches from spineless sago, short spine sago, and long spine sago shown same in the XRD pattern where the peak was around $2 \theta=5^{\circ}, 15^{\circ}, 17^{\circ}, 23^{\circ}$, and $27^{\circ}$. This pattern give information that the XRD diffractograms of three types of sago starches were C-type crytallinities which an intermediate to that of cereal (typeA) and tuber (type-B) starches, and this result agreed with previous study on native sago starch reported by Adawiyah et al., (2013). The pattern was determined by the branching pattern of amylopectin played a key role in determining the type of crystallinity. From their pattern indicated that native starch of three type's sago did not disrupt during their preparation.

According to (Liu et al. 2011), the degree of relative crystallinity of native starch depending on their botanical sources, such as maize was $23.09 \%$ and potato was $30.3 \%$. The crystallinity of the native starch granules varying from $15 \%$ to $45 \%$. Furthermore, in the hydrolysis of starch, at the beginning process, the hydrolysis occurs rapidly in the amorphous region containing the branching point $\alpha-1,6$ of the amylopectin molecule and most of the amylose. Then, the hydrolysis process occurs slowly in the crystalline area. Data of the relative crystallinities of native sago were not significantly different among those sago types with range $34.4 \%$ to $36.2 \%$ (Table 2 ). The three types of sago did not differ in energy and time needed for hydrolyzing. Meanwhile, when the sago starch compared to corn and potato starch, sago starch needed longer energy and time to hydrolyze. However, the relative crystalline of native sago starch can be changed and reduced if the starch undergoes gelatinization, because the semi-crystalline in native starch granules converted to an amorphous structure (Hasjim et al. 2013). Santoso et al., (2015) found that the relative crystalline of sago starch will be reduced from $30.5 \%$ to $11.2 \%$ when the starch milled using narrow clearance, which had been a conversion from a polycrystalline state to an amorphous state.

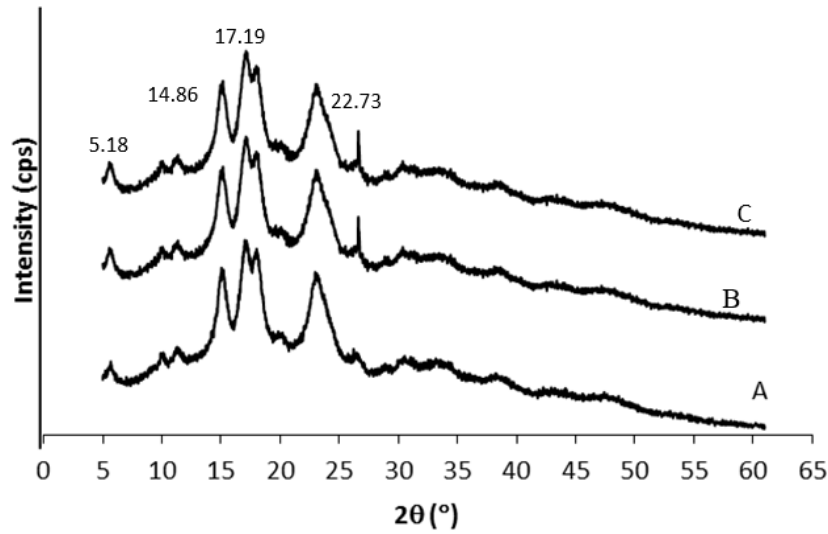

Figure 3. X-ray diffraction patterns of sago starch. A. Spineless sago, B. Short spines sago, C. Long spines sago 
Table 3. Amilograph characteristics of sago starch

\begin{tabular}{|c|c|c|c|c|}
\hline Type of sago & $\begin{array}{c}\text { Peak viscosity } \\
\text { (cP) }\end{array}$ & $\begin{array}{c}\text { Break down } \\
(\mathrm{CP})\end{array}$ & $\begin{array}{c}\text { Set back } \\
(\mathrm{cP})\end{array}$ & $\begin{array}{c}\text { Pasting temp. } \\
\left({ }^{\circ} \mathrm{C}\right)\end{array}$ \\
\hline Spineless sago (A) & $7571.0 \pm 113.14 a$ & $5434.0 \pm 94.75 a$ & $1495.0 \pm 91.92 \mathrm{a}$ & $74.65 \pm 1.50 \mathrm{a}$ \\
\hline Short spines sago (B) & $1271.0 \pm 132.94 b$ & $978.0 \pm 106.07 \mathrm{~b}$ & $538.0 \pm 56.57 \mathrm{c}$ & $75.80 \pm 1.56 \mathrm{a}$ \\
\hline Long spines sago (C) & $7608.0 \pm 111.72 \mathrm{a}$ & $5668.0 \pm 91.92 \mathrm{a}$ & $923.0 \pm 52.33 b$ & $75.45 \pm 0.92 a$ \\
\hline
\end{tabular}

Note: *Value followed by different letter within a column of each treatment indicate a significantly different $(\mathrm{P}<0.05)$

\section{Viscosity}

Gelatinization is the process of breaking bonds between starch molecules in the presence of water and heat, as well allows starch molecules to bind more water. The presence of water penetration will increase randomness in the structure of starch. Then, the stronger the bonds between starch molecules cause a higher amount of heat needed to break bonds between molecules and then increase the gel temperature. Viscosity of starch was measured using a Rapid Visco Analyser (RVA).

The gelatinization profile of spineless sago, short spines sago, and long spines sago was summarized in Table 3. According to Nadiha et al. (2010), peak viscosity is associated with protein and fat on the surface of the granules and does not correlate with amylose content. Since the fat $(0.13-0.35 \% \mathrm{db})$ and protein $(1.11-1.35 \% \mathrm{db})$ content of the three types in this study (Tabel 1) were relatively low then it was not influencing the peak viscosity. However, the peak viscosity, breakdown, setback, and pasting temperature of short spines sago was lower than the other two types of sago. These differences in the swelling power were probably caused by the variation in structural organization and characteristics of the starch granules obtained from different botanical sources or crops (Singh et al. 2010). Adawiyah et al. (2013) reported that differences in amylopectin crystalline structure could affect gelatinization properties. Vamadevan and Berfort (2020) investigated four different types of amylopectin structure that affected granule swelling, which contributes to viscofying properties of starches. Interaction between branched amylose and amylopectin backbone retard swelling granule, while long amylose chains, more typical for linear amylose, retards the swelling of granules containing Types 1 and 3 amylopectins (Vamadevan and Bertfort 2020).

Based on the result of this study, we recommend that the gel which has high peak viscosity and setback (spineless and long spine sago starch) is suitable for development as thickener and fillers. While, the short spine sago starch with low in peak viscosity and setback tendency to slow retrogradation process in final product, then suggested for cakes and bakery products because not to harden when the product is cold (Nadiha et al. 2010).

In conclusion, starch morphology for the three types of sago based on the SEM had an oval shape with a smooth surface and was dominated by a $40 \mu \mathrm{m}$ size, which indicates that the starch granules did not disrupt during the preparation process, which was also proved by the x-ray diffraction analysis. Fat content of three types of sago was from $0.13 \%(\mathrm{db})$ to $0.35 \%(\mathrm{db})$; protein was from $1.11 \%$ (db) to $1.35 \%(\mathrm{db})$; carbohydrate was from $96.95 \%(\mathrm{db})$ to $97.72 \%(\mathrm{db})$; ash content was ranged from $0.07 \%(\mathrm{db})$ to $0.09 \%(\mathrm{db})$. The proximate composition of starch from the three types of sago was not significantly different, except protein of spineless sago type differed slightly higher but it did not affect the profile and gelatinization process of the starch. Based on the amylose content, all types of sago had high amylose content, then more suitable for the paper and textile industries. Sago starches of spineless type and long spines sago had high peak viscosity and setback and can develop as thickener and fillers. The starch from short spines sago had a low in peak viscosity and setback, suggested for cakes and bakery products because not to harden when the product is cold.

\section{ACKNOWLEDGEMENTS}

The authors would like to thank the Ministry of Research and Technology-Higher Education, Republic of Indonesia for funding through the National Strategic Research Grant in 2019, with contract number: 198/SP2H/LT/DRPM/2019.

\section{REFERENCES}

Achudan SN, Mohamed AMD, Abd Rashid RS, Mittis P. 2020. Yield and physicochemical properties of starch at different sago palm stages. Materials Today: Proceeding. DOI: 10.1016/j.matpr.2020.01.341.

Adawiyah DR, Sasaki T, Kohyama K. 2013. Characterization of arenga starch in comparison with sago starch. Carbohydr Polym 92: 23062313. DOI: 10.1016/j.carbpol.2012.12.014.

Alvani K, Qi X, Tester RF, Snape CE. 2011. Physico-chemical properties of potato starches. Food Chem 125: 958-965. DOI: 10.1016/j.foodchem.2010.09.088

AOAC [Association of Analytical Chemists]. 2005. Official Methods of Analysis of AOAC Intl.. 16 ${ }^{\text {th }}$ ed. Method 931.04; method 970.39. Association of Analytical Chemists, Wahington, DC, USA.

Barrera GNG, Calderón-Domínguez J, Chanona-Pérez GF, GutiérrezLópez AE, León PD, Ribotta. 2013. Evaluation of the mechanical damage on wheat starch granulesby SEM, ESEM, AFM and texture image analysis. Carbohydr Polym 98: 1449-1457. DOI: 10.1016/j.carbpol.2013.07.056.

Bhat R, Abdullah N, Hj Din R, Tay, GS. 2013. Producing novel sago starch based food packaging films by incorporating lignin isolated from oil palm black liquor waste. J Food Eng 119 (4): 707-713. DOI: 10.1016/j.jfoodeng.2013.06.043.

Cai J, Cai C, Man J, Zhou W, Wei C. 2014. Structural and functional properties of C-type starches. Carbohydr Polym 101: 289-300. DOI: 10.1016/j.carbpol.2013.09.058.

Darma, Istalaksana P. 2011. Traditional processing of sago in Papua Province. In: Proceedings of the $10^{\text {th }}$ International Sago Symposium. Bogor, Indonesia. 
Dewi RK, Bintoro MH, Sudrajat. 2016. Morphological characteristics and yield potential of sago palm (Metroxylon spp.) accessions in South Sorong District, West Papua. J Agron Indonesia 44: 91-97.

Gujral H, Rosell CM. 2004. Modification of the pasting properties of wheat starch by cyclodextrin glycosyltransferase. J Sci Food and Agric 84: 1685-1690.

Hasjim J, Li E, Dhital S. 2013. Milling of rice grains: Effects of starch/flour structures on gelatinization and pasting properties. Carbohydr Polym 92: 682-690.

Konuma H. 2018. Status and Outlook of Global Food Security and the Role of Underutilized Food Resources: Sago Palm. In: Hiroshi Ehara, Yukio Toyoda, and Dennis V. Johnson (eds.). Sago Palm: Multiple Contribution to Food Security and Sustainable Livelihoods. Springer Open. Tokyo, Japan: 3-16.

Labuza, T.P. 1984. Moisture Sorption: Practical Aspect of Isotherm Measurement and Use. American Association of Cereal Chemists. Minnesota, USA

Li X, Gao W, Jiang Q, Hao J, Guo X, Huang L. 2012. Physicochemical, morphological, structural, and thermal characteristics of starches separated from Bulbus fritillaria of different cultivars. Starch/Stärke 64: $572-580$.

Limbongan J. 2007. Morphological of several of potential sago Types in Papua. Jurnal Litbang Pertanian 26 (1):16-24. [Indonesian]

Liu TY, Ma Y, Yu SF, Shi J, Xue S. 2011. The effect of ball milling treatment on structure and porosity of maize starch granule. Innov Food Sci Emerg Technol 12: 586-593. DOI 10.1016/j.ifset.2011.06.009.

Meullnett JF, BP Marks, JA Hankins, VK Griffin, MG Daniels. 2000 Sensory quality of cooked long grain rice as affected by rough rice moisture content, storage temperature, and storage duration. Cereal Chem 77: 259-263.

Muhidin, Sitti L, Syamsu A, Teguh W. 2016. Comparative studies on different agroecosystems base on soil physicochemical properties to development of sago palm on dry land. Intl J Chem Tech Res 9 (8): 511-518.

Nadiha MZN, Fazilah A, Bhat R, Karim AA. 2010. Comparative susceptibilities of sago, potato and corn starches to alkali treatment. Food Chem 121: 1053-1059. DOI: 10.1016/j.foodchem.2010.01.048.
Santoso B, Sakakura K, Naito H, Ohmi M, Nishimura Y, Uchiyama T, Itaya A, Hisamatsu M, Ehara H, Mishima T. 2015. Effects of micro powder milling on physicochemical properties of sago starch. J Appl Glycosci 62 (2): 73-80.

Singh S, Singh N, Isono N, Noda T. 2010. Relationship of granule size distribution and amylopectin structure with pasting, thermal, and retrogradation properties in wheat starch. J Agric Food Chem 58: 1180-1188.

SNI [Indonesian National Standard]. 1995. Sago Starch. SNI-01-37291995. Badan Standarisasi Nasional, Jakarta. [Indonesian].

SNI [Indonesian National Standard]. 2011. Tapioka. SNI-03451: 2011. Badan Standarisasi Nasional, Jakarta. [Indonesian].

Steffe JF. 1996. Rheological methods in food processing engineering. $2^{\text {nd }}$ ed. Freeman Press, East Lansing, USA.

Uthumporn U, Wahidah N, Karim AA. 2014. Physicochemical properties of starch from sago (Metroxylon sagu) palm grown in mineral soil at different growth stages. IOP Conf Ser Mater Sci Eng 62: 1-11. DOI: $10.1088 / 1757-899 X / 62 / 1 / 012026$.

Vamadevan V, Bertfort E. 2020. Observations on the impact of amylopectin and amylose structure on the swelling of starch granules. Food Hydrocoll 103: 105-116. DOI: 10.1016/j.foodhyd.2020.105663.

Yamamoto, Y. 2011. Starch Productivity of Sago Palm and the Related Factors. In: Siregar IZ, Sudaryanto T, Ehara H, Suwardi, Lubis I, Ardie SW (eds.). Proceeding of Sago for Food Security, Bio-Energy, and Industry, from Research to Market. The $10^{\text {th }}$ International Sago Symposium. October 2011. IPB (Institut Pertanian Bogor), Bogor.

Yater T, Tubur HW, Meliala C, Abbas B. 2019. A comparative study of phenotypes and starch production in sago palm (Metroxylon sagu) growing naturally in temporarily inundated and non-inundated areas of South Sorong, Indonesia. Biodiversitas 20 (4): 1121-1126.

Zeng J, Li G, Gao H, Ru Z. 2011. Comparison of A and B starch granules from three wheat varieties. Molecules 16: 10570-10591. DOI: 10.3390/molecules161210570.

Zhang L, Zuo B, Wu P, Wang Y, Gao, W. 2012. Ultrasound effects on the acetylation of dioscorea starch isolated from Dioscorea zingiberensis C. H. Wright. Chem Eng Process 54: 29-36.

Zhu F. 2019. Review: Recents advanced in modifications and applications of sago starch. Food Hydrocoll. 96: 412-423. 